\title{
ЗАБЕЗПЕЧЕННЯ ЯКОСТІ ОСВІТИ ДІТЕЙ РАННЬОГО ТА ДОШКІЛЬНОГО ВІКУ У ПРИВАТНОМУ СЕКТОРІ: НАУКА I ПРАКТИКА
}

https://doi.org/10.37472/2707-305X-2021-3-1-5-5

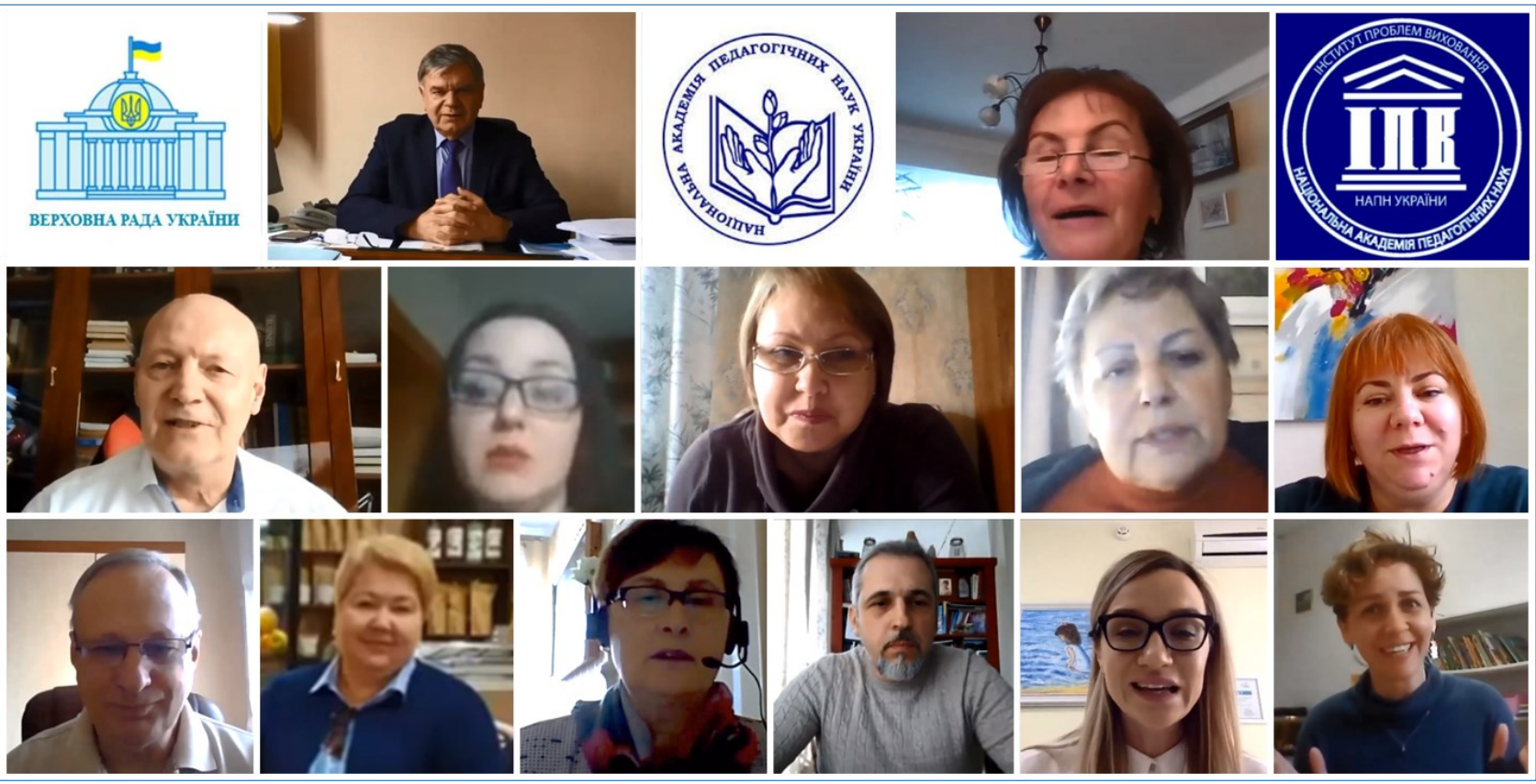

КАНIШЕВСЬКА

Любов Вікторівна

доктор педагогічних наук,

професор, заступник

директора з науково-

експериментальної роботи

Інституту проблем

виховання Національної

академії педагогічних наук

України, м. Київ, Україна

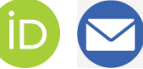

Анотація. 6 квітня 2021 р. Відділенням загальної педагогіки та філософії освіти Національної академії педагогічних наук України, Інститутом проблем виховання НАПН України разом із підкомітетом з питань раннього розвитку та дошкільної освіти Комітету Верховної Ради України проведено вебінар на тему: "Забезпечення якості освіти дітей раннього та дошкільного віку у приватному секторі: наука і практика». У роботі вебінару взяли участь учені Інституту проблем виховання й інших установ НАПН України, працівники Міністерства освіти і науки України, Державної служби якості освіти України, науковці, представники закладів вищої освіти, директори, засновники, педагоги приватних закладів дошкільної освіти та інші. Вебінар присвячено актуальним проблемам сучасної дошкільної освіти у приватному секторі: забезпеченню якості освіти дітей раннього та дошкільного віку; упровадженню сучасних освітніх методик і технологій в освітній процес; налагодженню співпраці всіх зацікавлених суб'єктів із закладами освіти дітей раннього та дошкільного віку приватної форми власності; реалізації стандарту дошкільної освіти в таких закладах.

Ключові слова: якість дошкільної освіти; діти раннього та дошкільного віку; приватні заклади дошкільної освіти; освітній прочес закладів дошкільної освіти; сучасні освітні методики і технологія.

6 квітня 2021 р. за участю Відділення загальної педагогіки та філософії освіти Національної академії педагогічних наук України, Інституту проблем виховання НАПН України разом із підкомітетом з питань раннього розвитку та дошкільної освіти Комітету Верховної Ради України проведено вебінар на тему: «Забезпечення якості освіти дітей раннього та дошкільного віку у приватному секторі: наука i практика». 
До роботи вебінару долучилися вчені Інституту проблем виховання й інших установ НАПН України, працівники Міністерства освіти і науки України, Державної служби якості освіти України, науковці, представники закладів вищої освіти, директори, засновники, педагоги приватних закладів дошкільної освіти та інші. У заході взяли участь понад 100 осіб.

Вебінар присвячено актуальним проблемам сучасної дошкільної освіти у приватному секторі:

- забезпеченню якості освіти дітей раннього та дошкільного віку;

- упровадженню сучасних освітніх методик і технологій в освітній процес;

- налагодженню співпраці всіх зацікавлених суб'єктів із закладами освіти дітей раннього та дошкільного віку приватної форми власності;

- реалізації стандарту дошкільної освіти в таких закладах.

У вітальному слові президента НАПН України, доктора філософських наук, професора, дійсного члена (академіка) НАН України і НАПН України Василя Кременя наголошено на актуальності та значущості для суспільства проблеми освіти дітей раннього і дошкільного віку та необхідності розвитку приватного сектору дошкільної освіти. Василь Григорович також висловив подяку голові підкомітету з питань раннього розвитку та дошкільної освіти Комітету Верховної Ради України з питань освіти, науки та інновацій Володимиру Воронову за ініціювання та розроблення разом із вченими НАПН України Концепції освіти дітей раннього та дошкільного віку.

3 вітальним словом до присутніх звернувся перший віце-президент НАПН України, доктор педагогічних наук, професор, дійсний член (академік) НАПН України Володимир Луговий, який підкреслив важливість забезпечення якості освіти дітей раннього та дошкільного віку у приватному секторі та упровадження сучасних освітніх методик і технологій в освітній процес приватних закладів.

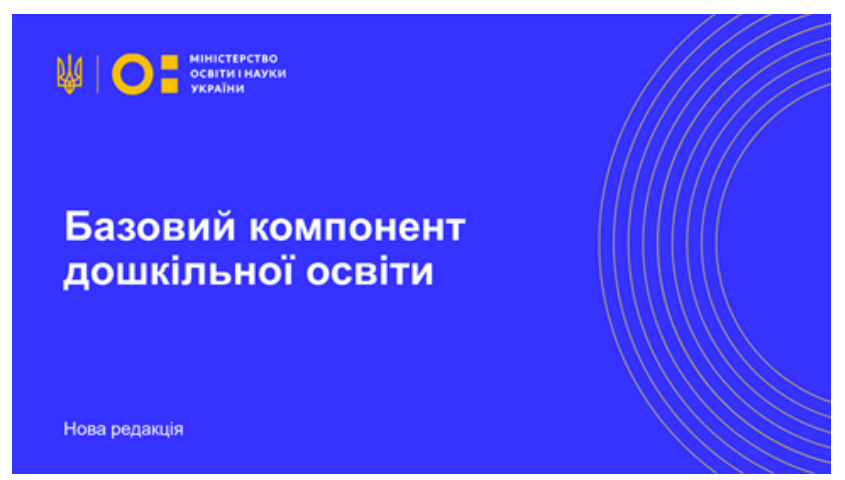

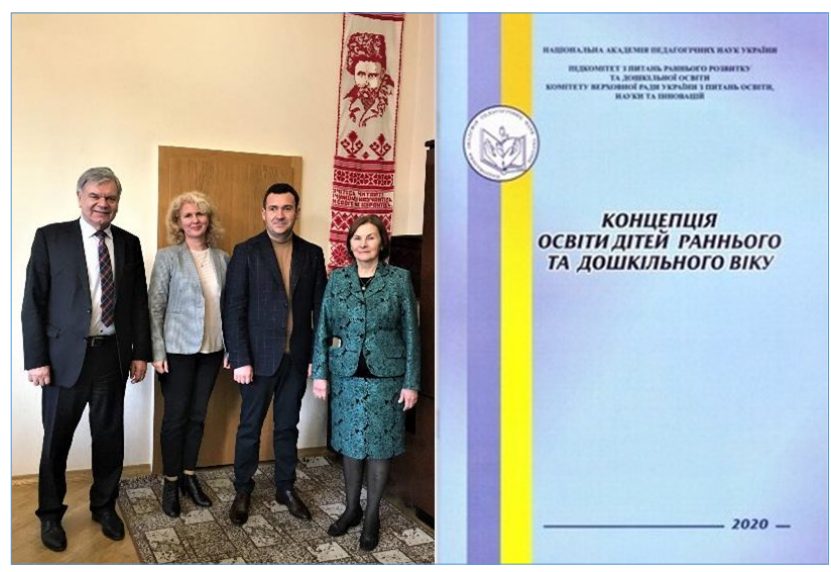

У своїй доповіді помічник народного депутата Володимира Воронова, юрист у сфері освітніх проєктів Ольга Льодіна зазначила, що під керівництвом Володимира Анатолійовича розроблено: методичний супровід для педагогів закладів дошкільної освіти спрощеного типу приватної форми власності; методику «Лідер живе в кожному», орієнтовану на дітей 2-3, 3-4, 4-5, 56 років; методику Mr. Leader Scanbook, що дає змогу досліджувати розвиток дитини протягом року.

Ольга Льодіна підкреслила, що майже завершено оновлення Закону України «Про освіту дітей раннього та дошкільного віку» (Закон України «Про дошкільну освіту»). У новому змісті Закону вперше зазначено про:

1) створення єдиної цифрової платформи;

2) створення умов для якісного ринку надання послуг у сфері дошкільної освіти;

3) створення центрів підтримки батьків;

4) підвищення престижності та якості професії працівника сфери освіти дітей раннього та дошкільного віку;

5) створення координуючої установи у сфері освіти дітей раннього та дошкільного віку;

6) зміну системи фінансування закладів дошкільної освіти (програма «гроші ходять за дитиною» - державний рівень);

7) можливість прийому до приватних закладів дітей від двох місяців.

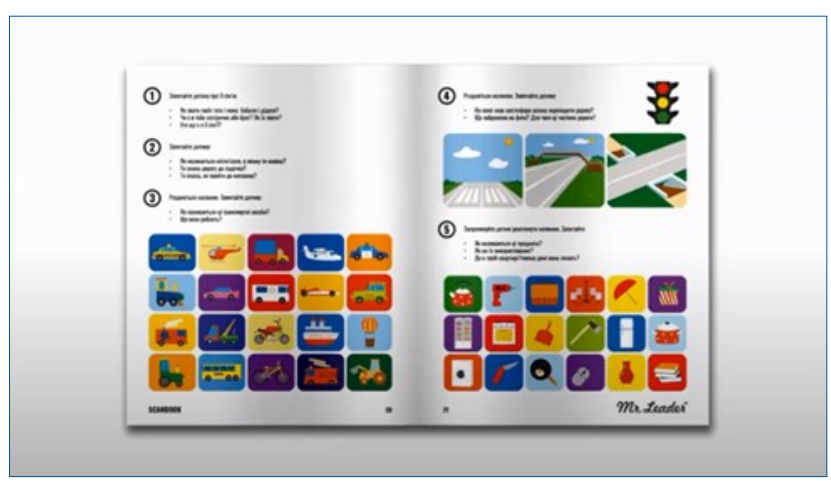


Модератором заходу була академік-секретар Відділення загальної педагогіки та філософії освіти НАПН України, доктор педагогічних наук, професор, дійсний член (академік) НАПН України Світлана Сисоєва.

Дієву участь у роботі вебінару взяли: начальник відділу дошкільної освіти департаменту дошкільної, шкільної, позашкільної та інклюзивної освіти МОН України Світлана Нерянова; директор департаменту інституційного аудиту Державної служби якості освіти України Юрій Вергун; голова Всеукраїнської асоціації працівників дошкільної освіти Ніна Омеляненко; співзасновник вальдорфського закладу дошкільної освіти «Сонях» Андрій Горський; директори приватних закладів дошкільної освіти м. Києва Валерія Дем'янова, Євгенія Островська.

Активною була участь вчених - докторів педагогічних наук Наталії Гавриш і Катерини Крутій, кандидата педагогічних наук Ольги рейпольськоїта ін.

Учасники вебінару відзначили, що стан вітчизняної дошкільної освіти потребує системних перетворень, пов'язаних із новими викликами щодо освіти дітей раннього та дошкільного віку. Необхідно враховувати і процеси цифровізації освіти, особливості діяльності приватного сектору дошкільної освіти, усіх учасників освітнього процесу - суспільства, вихователів цих закладів, дітей та їхніх батьків. Ураховуючи наведене, закономірним є подальше різновекторне розгортання практико орієнтованих досліджень для забезпечення якості освіти дітей раннього та дошкільного віку, зокрема у приватному секторі, розроблення нового Закону України
«Про освіту дітей раннього та дошкільного віку» (Закон України «Про дошкільну освіту»).

Плідна наукова дискусія учасників вебінару сприяла не лише глибшому розумінню проблематики освіти дітей у приватному секторі, а й утвердженню консолідованої позиції щодо розвитку освіти дітей раннього та дошкільного віку в Україні. Це можливо за умов об'єднання зусиль підкомітету з питань раннього розвитку та дошкільної освіти Комітету Верховної Ради України з питань освіти, науки та інновацій, учених НАПН України, фахівців МОН України, Державної служби якості освіти України, викладачів закладів вищої освіти, вихователів закладів дошкільної освіти та громадських організацій (рекомендації додаються).

\section{СПИСОК ВИКОРИСТАНИХ ДЖЕРЕЛ}

Воронов, В.А., Гавриш, Н.В., Канішевська, Л.В., Піроженко, Т.О., Рейпольська, О.Д., \& Сисоєва, С.О. (Укл.). (2020). Концепиія освіти дітей раннього та дошкільного віку. НАПН України. Київ. ФОП Ференець В.Б. https://bit.ly/2E3xuLJ

Інститут проблем виховання НАПН України. (2021, 7 квітня). Забезпечення якості освіти дітей раннього та дошкільного віку у приватному секторі: наука і практика [Відео]. YouTube. https:// youtu.be/tv8HHILJMwA

Міністерство освіти і науки України. (2021, 21 січня). Про затвердження Базового компонента дошкільної освіти (Державного стандарту дошкільної освіти) нова редакція (33). https://bit.ly/39UTWUn

Національна академія педагогічних наук України. (2021, 6 квітня). Вебінар із проблематики освіти dimей раннього ma дошкільного віку. http:// naps.gov.ua/ua/press/releases/2273/

Сисоєва, С.О., \& Рейпольська, О.Д. (2020). Концепція освіти дітей раннього та дошкільного віку: новий погляд. Вісник Національної академії педагогічних наук України, 2(1). https://doi.org/10.37472/2707305X-2020-2-1-2-2

\section{ENSURING THE QUALITY OF EARLY CHILDHOOD AND PRESCHOOL EDUCATION IN THE PRIVATE SECTOR: SCIENCE AND PRACTICE}

Liubov Kanishevska

DSc in Pedagogy, Professor, Deputy Director for Scientific and Experimental Work, Institute of

Problems on Education of the National Academy of Educational Sciences of Ukraine, Kyiv, Ukraine

Abstract. On April 6, 2021, the webinar "Ensuring the Quality of Early Childhood and Preschool Education in the Private Sector: Science and Practice" was held by the Department of General Pedagogy and Philosophy of Education of the National Academy of Educational Sciences of Ukraine, Institute of Problems on Education of NAES of Ukraine together with the Subcommittee on Early Development and Preschool Education of the Verkhovna Rada of Ukraine Committee on Education, Science and Innovations. The representatives of the Ministry of Education and Science of Ukraine, State Service of Education Quality of Ukraine, higher education institutions, preschool education institutions' founders, leaders, teachers, etc. attended the event. Key webinar themes were: ensuring the quality of early childhood and preschool education in the private sector; implementing modern training methods and technologies in the educational process of private preschool education institutions; establishing cooperation of all stakeholders with private education institutions for children of early and preschool age; realizing the Standard for Preschool Education in the private preschool education institutions.

Keywords: quality of preschool education; children of early and preschool age; private preschool education institutions; educational process of preschool education institutions; modern training methods and technologies.

Дата публікації: 12 квітня 2021 р. 


\section{РЕКОМЕНДАЦІї \\ вебінару «Забезпечення якості освіти дітей раннього та дошкільного віку у приватному секторі: наука і практика» \\ (6 квітня 2021 р., м. Київ)}

6 квітня 2021 р. Відділенням загальної педагогіки та філософії освіти Національної академії педагогічних наук України, Інститутом проблем виховання НАПН України разом із підкомітетом з питань раннього розвитку та дошкільної освіти Комітету Верховної Ради України проведено вебінар на тему: «Забезпечення якості освіти дітей раннього та дошкільного віку у приватному секторі: наука і практика».

У роботі вебінару взяли участь учені Інституту проблем виховання й інших установ НАПН України, працівники Міністерства освіти і науки України, Державної служби якості освіти України, науковці, представники закладів вищої освіти, директори, засновники, педагоги приватних закладів дошкільної освіти та інші.

Mema проведення вебінару: актуалізація питань щодо забезпечення якості освіти дітей раннього та дошкільного віку у приватному секторі; упровадження сучасних освітніх методик і технологій в освітній процес приватних закладів дошкільної освіти; налагодження співпраці всіх зацікавлених суб'єктів із закладами освіти дітей раннього та дошкільного віку приватної форми власності.

Учасниками вебінару наголошено, що освіта дітей раннього та дошкільного віку є самоцінною первинною ланкою системи безперервної освіти, яка закладає підґрунтя розвитку особистості для навчання впродовж життя. Згідно із законодавством України дошкільна освіта для дітей старшого дошкільного віку (із п'яти років) $є$ обов'язковою.

Метою якісної освіти дітей раннього та дошкільного віку $€$ забезпечення гармонійного фізичного, психічного, розумового, духовно-морального розвитку особистості, їі фізичного і психічного здоров'я, виховання ціннісного ставлення до себе й світу, формування механізмів соціалізації, творчого самовизначення та саморозвитку в різних умовах життєдіяльності.

Зміна цілей освіти, зміщення акцентів зі знаннєвого на компетентнісний підхід зумовлюють нове бачення якісної освіти дітей раннього та дошкільного віку. Європейський парламент та Рада Європейського Союзу схвалили Рамкову програму оновлення ключових компетентностей для навчання впродовж життя, до яких віднесено такі: грамотність; мовна; математична компетентність та компетентність у науках, технологіях та інженерії; цифрова; особиста, соціальна та навчальна; громадянська; підприємницька; культурної обізнаності та самовираження ${ }^{1}$. Сучасна освіта дітей раннього та дошкільного віку має відповідати світовим та європейським освітнім тенденціям, соціокультурним цінностям країни, бути спроможною задовольнити вимоги та потреби громадян українського суспільства.

Система забезпечення якості у сфері освіти дітей раннього та дошкільного віку у приватному секторі формується відповідно до Закону України «Про освіту» ${ }^{2}$ з урахуванням визначених ним особливостей та охоплює систему внутрішнього та зовнішнього забезпечення якості освіти, а також інструменти, процедури та заходи її підвищення (стандартизацію, ліцензування, громадську акредитацію, інституційний аудит, моніторинг якості освітньої діяльності у сфері дошкільної освіти, атестацію та сертифікацію педагогічних працівників).

Згідно із сучасними науковими підходами якість дошкільної освіти характеризують як відповідність освітніх результатів навчання і виховання вимогам, установленим законодавством, відповідним стандартом освіти та/ або договором про надання освітніх послуг. Це поняття є багатоаспектним і охоплює якість: цілепокладання; освітнього процесу; освітнього результату; створеного освітнього середовища; психолого-педагогічних умов; управління закладом дошкільної освіти.

Учасники вебінару відзначили, що стан вітчизняної дошкільної освіти потребує системних перетворень, пов'язаних із новими викликами щодо освіти дітей раннього та дошкільного віку, необхідністю враховувати процеси цифровізації освіти, діяльності приватного сектору дошкільної освіти, усіх учасників освітнього процесу - суспільства, вихователів, дітей та їхніх батьків. Особливо гостро постала проблема освіти дітей раннього віку (від 0 до 3 років). Унаслідок дефіциту загальної та педагогічної культури окремих батьків рівень розвитку дітей цієї вікової категорії нині не повною мірою відповідає загальноприйнятим нормам.

За роки незалежності в Україні, паралельно з розвитком державної системи дошкільної освіти, сформувався приватний сектор, який створив конкуренцію у сфері надання освітніх послуг, зумовлену потребою збільшення кількості закладів дошкільної освіти.

Водночас недосконалість нормативно-правового забезпечення та політика несприйняття закладів дошкільної освіти приватної форми власності загальмували розвиток цього сектору дошкільної освіти.

Учасники вебінару наголосили на необхідності унормування діяльності закладів дошкільної освіти приватної форми власності для створення психолого-педагогічних умов щодо організації предметно-

\footnotetext{
${ }^{1}$ Національна академія педагогічних наук України. (2018). Національний освітньо-науковий глосарій. Київ: ТОВ «КОНВІ ПРІНТ». https://lib.iitta.gov.ua/715512/

2 Закон України «Про освіту». (2017, 5 вересня). https://zakon.rada.gov.ua/laws/show/2145-19
} 
просторового середовища, дотримання вимог Базового компонента дошкільної освіти, чинних програм і забезпечення належного контролю/оцінки якості освіти відповідними органами (Державна служба якості освіти України).

Орієнтиром якості результатів дошкільної освіти України є Базовий компонент дошкільної освіти як ії державний стандарт. Усі заклади дошкільної освіти (державні та приватні) мають дотримуватися вимог до рівня розвитку та вихованості дитини дошкільного віку, визначених цим стандартом. Для оптимального моніторингу створено ефективний багатофункціональний інструментарій, який дає змогу об'єктивно проаналізувати дотримання освітніми закладами вимог Базового компонента дошкільної освіти. Освіта дітей раннього віку вимагає упровадження психолого-педагогічного патронажу дітей, організації груп раннього віку з гнучким графіком роботи.

Подальшому запровадженню системи моніторингу та оцінки дошкільної освіти мають сприяти розроблення нормативно-правових і науково-методичних засад та формування порядку інституційного аудиту закладів дошкільної освіти, зокрема, вдосконалення критеріїв та індикаторів оцінювання якості роботи груп раннього та дошкільного віку, роботи закладу загалом. 3 огляду на те, що чинний зміст Базового компонента дошкільної освіти орієнтований на оцінку остаточного результату дошкільної освіти - відстеження динаміки особистісних досягнень старших дошкільників - $€$ невідкладна потреба в розробленні нормативно-правових і науково-методичних засад моніторингу якості роботи груп раннього та дошкільного віку (молодший і середній дошкільний вік).

Учасники вебінару вважають актуальним подальше різновекторне розгортання практико орієнтованих досліджень щодо забезпечення якості освіти дітей раннього та дошкільного віку, зокрема у приватному секторі, розроблення нового Закону України «Про освіту дітей раннього та дошкільного віку» (Закон України «Про дошкільну освіту»).

За результатами всебічного обговорення ухвалено рекомендації.

Членам Національної академії педагогічних наук України та вченим ії наукових установ:

- уточнити тематику та зміст досліджень у наукових установах НАПН України з урахуванням виявлених нових тенденцій і викликів освіти дітей раннього та дошкільного віку у приватному секторі;

- з огляду на запити сьогодення запровадити наукові дослідження з питань забезпечення якості освіти дітей раннього та дошкільного віку у приватному секторі дошкільної освіти;

- розширити партнерство з інституціями громадянського суспільства, неурядовими організаціями у реалізації фундаментальних і прикладних досліджень, підготовці й упровадженні науково-методичної та популярної літератури, проведенні інформаційно-просвітницьких заходів;

- поглибити вивчення зарубіжного досвіду щодо функціонування центрів раннього розвитку дитини, закладів дошкільної освіти та забезпечення якості освіти дітей раннього віку;

- активізувати висвітлення результатів наукових досліджень із дошкільної освіти в наукових фахових виданнях, зокрема включених до міжнародних наукометричних баз даних;

- активізувати взаємодію із засобами масової інформації з метою спільної підготовки відповідних теле- та радіопередач, ширшого висвітлення позитивних тенденцій і явищ у вітчизняній освіті дітей раннього та дошкільного віку.

Міністерству освіти і науки України:

- сприяти розвитку мережі закладів освіти дітей раннього віку приватної форми власності;

- популяризувати й узагальнювати кращий досвід приватних закладів дошкільної освіти, зокрема освіти дітей раннього віку;

- сприяти розвитку державно-приватного партнерства в управлінні дошкільною освітою, стимулюванню батьківського партнерства.

Кафедрам дошкільної та початкової освіти педагогічних закладів вищої освіти:

- модернізувати зміст професійної підготовки педагогічних працівників, здатних ефективно діяти в умовах системних змін в освіті дітей раннього віку.

Міністерству соціальної політики України:

- сприяти створенню соціальних центрів із формування в молоді відповідального батьківства;

- розробити механізми контролю за коштами, виділених батькам на утримання й освіту дітей раннього віку.

Міністерству охорони здоров'я України:

- запровадити при дитячих поліклініках службу психолого-педагогічного патронажу розвитку дітей від 0 до 3 років із покриттям коштів із соціальних виплат батькам.

Рекомендації вебінару НАПН України опублікувати на сайті НАПН України і сприяти їх поширенню й обговоренню.

Пропозиції та доповнення до рекомендацій вебінару просимо надсилати на електронну адресу: ipv_info@ukr.net. 